\title{
Characterization of subglacial marginal channels using 3-D analysis of high-density ground-penetrating radar data
}

\section{Article}

Cite this article: Egli PE, Irving J, Lane SN (2021). Characterization of subglacial marginal channels using 3-D analysis of high-density ground-penetrating radar data. Journal of Glaciology 67(264), 759-772. https://doi.org/ 10.1017/jog.2021.26

Received: 17 September 2020

Revised: 18 February 2021

Accepted: 19 February 202

First published online: 18 March 2021

\section{Key words:}

Glacial geomorphology; glacier hydrology; ground-penetrating radar; mountain glaciers; subglacial processes

\section{Author for correspondence:}

Pascal E. Egli, E-mail: pascal.egli@unil.ch
Pascal E. Egli ${ }^{1}$ (I) James Irving ${ }^{2}$ (1) and Stuart N. Lane ${ }^{1}$

${ }^{1}$ Institute of Earth Surface Dynamics, University of Lausanne, Lausanne, Switzerland and ${ }^{2}$ Institute of Earth Sciences, University of Lausanne, Lausanne, Switzerland

\section{Abstract}

Studying subglacial drainage networks is important for understanding the potential relationship between channel dynamics and rapid glacier recession as well as the role of subglacial channels in subglacial sediment evacuation. In order to delineate the planform geometry of snout marginal subglacial channels, densely spaced ground-penetrating radar (GPR) measurements at a frequency of $\sim 70 \mathrm{MHz}$ were carried out over the snout marginal zones of two temperate glaciers in the southwestern Swiss Alps, the Haut Glacier d'Arolla and the Glacier d'Otemma. Three-dimensional (3-D) data processing and amplitude analysis of the GPR reflection along the glacier bed was used to map the channels. At the Haut Glacier d'Arolla, two relatively straight channels of several meters in width were identified. The positions of these channels correspond well with the locations of channel outlets at the glacier terminus, as well as with fractures appearing on the glacier surface one month after the GPR data acquisition. The latter are believed to represent the beginning of ice collapse above the subglacial channels. At the Glacier d'Otemma, a major subglacial conduit was detected with similar dimensions to those identified at the Haut Glacier d'Arolla, but greater sinuosity. The position of this channel was confirmed by drone-based imagery acquired after glacier margin collapse. Our results confirm that high-density 3-D GPR surveys can be used to map subglacial channels near temperate alpine glacier margins.

\section{Introduction}

Understanding the hydrology of alpine glaciers, and in particular the geometry and dynamics of the channels that form within and beneath glacier ice, has been an important research interest since at least the 1950s (Fountain and Walder, 1998). It is well-established that subglacial drainage may occur via semicircular Röthlisberger channels carved into glacier ice (Röthlisberger, 1972), Nye channels eroded into bedrock (Nye, 1959), channels carved into both subglacial sediments and ice (Walder and Fowler, 1994) or some combination thereof. Although we know that subglacial channels may be either pressurized or open to the atmosphere, their geometry and behavior under given flow conditions are not well understood. Learning more about the pathways of channels close to the terminus of glaciers may provide important knowledge about their origin and dynamics. For instance, if a channel meanders strongly, its shape is likely a result of interactions with the glacier bed such as erosion, deposition, sediment transport and deviation by bedrock outcrops (Alley and others, 1997). Such knowledge is critically important for understanding how glaciers transfer eroded sediment through their marginal zones and for parameterizing models of subglacial sediment export (Beaud and others, 2018; Perolo and others, 2019).

Despite the importance of quantifying subglacial channels, the last 25 years have not changed the fundamental observation of Walder and Fowler (1994) that little data are available to provide details on their geometry. This is not surprising as accessing such channels is difficult. Glacial speleological methods have yielded valuable information (Benn and others, 2009a, 2009b; Gulley and others, 2009, 2012a, 2012b, 2014; Mankoff and others, 2017; Temminghoff and others, 2019), but entry during the melt season may not be possible and channels must be large and stable enough for physical access.

One alternative is ground-penetrating radar (GPR). GPR has a long history of use in the field of glaciology, which began over a half century ago in the form of radio-echo sounding $(\sim 1-40 \mathrm{MHz})$ to map the thickness of glaciers and ice sheets (e.g. Steenson, 1951; Cook, $1960)$. Since that time, GPR has grown to become a standard glaciological tool and its applications have greatly expanded (e.g. Plewes and Hubbard, 2001; Bingham and Siegert, 2007; Schroeder and others, 2020). In the context of alpine glaciers, the GPR method has been successfully used (i) to map internal layering; (ii) to identify crevasses and shear zones; (iii) to assess and to monitor the nature of the glacier bed; (iv) to map internal water bodies; (v) to estimate ice water content; (vi) to distinguish between regions of cold and temperate ice and (vii) to identify, characterize and monitor englacial and subglacial channels. Many of these applications require GPR antenna frequencies of $50 \mathrm{MHz}$ or higher (i.e. greater than those typically employed for ice thickness determination) as our ability to resolve subsurface 
Fig. 1. Location of the field sites in southwestern Switzerland. The black square on the insert map indicates the region covered by the satellite photo showing (1) the Haut Glacier d'Arolla and (2) the Glacier d'Otemma. The glacier outlines correspond to the most recent GLIMS data (Paul and others, 2019), and are based on satellite imagery from 2015. The red squares near the end of each glacier tongue indicate the location of the GPR datasets analyzed in this study. The background satellite image was obtained from 2019 imagery (Planet Team, https://api.planet.com). The insert map was obtained from the Swiss Federal Office of Topography (http://map.geo.admin.ch). Please note that all coordinates in the figures of this paper are given in meters in the local Swiss coordinate system 'CH1903+'.

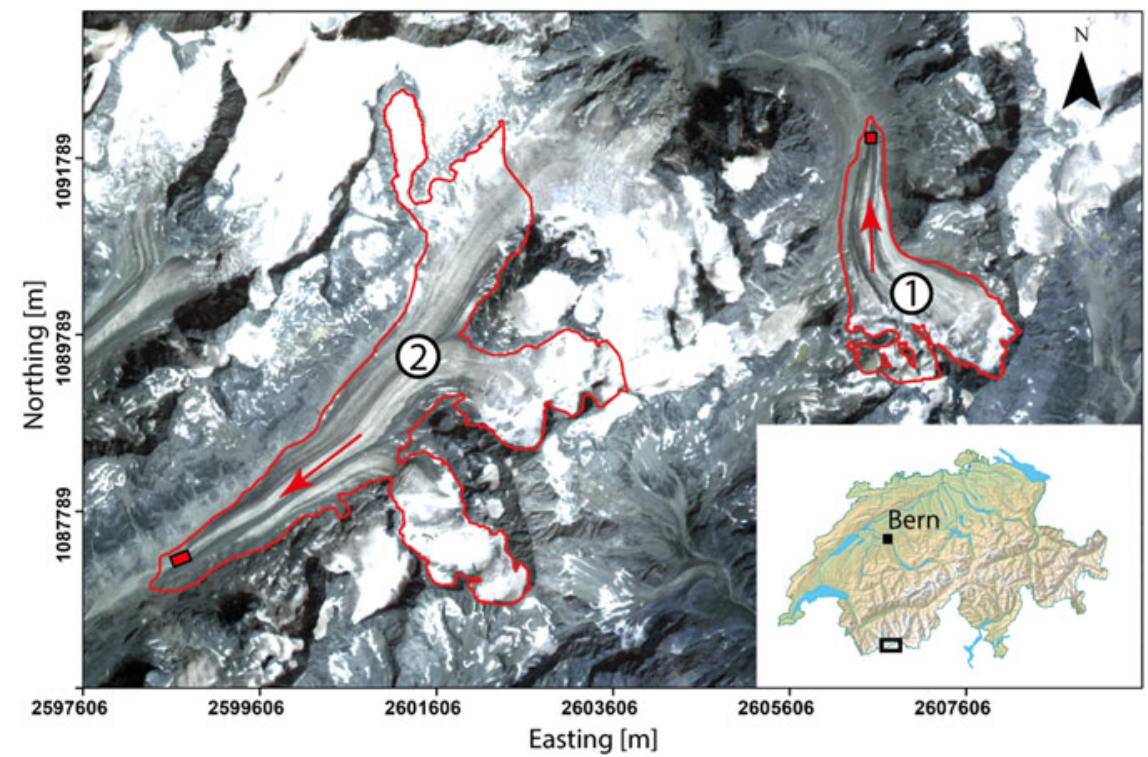

detail increases with the antenna frequency, albeit at the cost of a reduced depth of investigation (Davis and Annan, 1989).

With respect to identifying the location and geometry of enand subglacial channels using GPR, virtually all previous attempts have been based upon two-dimensional (2-D) profiles, or at the very most quasi-three-dimensional (3-D) surveys involving multiple parallel 2-D acquisitions with a large spacing between the survey lines (e.g. Zirizzotti and others, 2010; Bælum and Benn, 2011; Church and others, 2019, 2020; Temminghoff and others, 2019). Although these types of surveys can provide highly useful information, they are limited in the sense that the corresponding data cannot be properly imaged and visualized in 3-D because of the strong sampling bias in the along-line direction and the high degree of spatial aliasing in the cross-line direction. As a result, previous research has successfully detected en- and subglacial channels, but has only rarely been able to confirm continuous pathways or provide detailed information on channel planform geometries (Church and others, 2020). Densely-spaced parallel GPR survey lines, processed within a fully 3-D framework, have the potential to overcome this limitation. Such surveys, which have become common and are highly valued in environmental and archeological applications of GPR (e.g. Grasmueck and others, 2005; Booth and others, 2008) are now feasible for glaciological applications thanks to the increased acquisition speed and portability of modern real-time-sampling GPR instruments, combined with improvements to real-time differential GPS navigation.

The objective of this study is the detection and the characterization of ice-marginal subglacial channels using highresolution, densely spaced, GPR measurements. To this end, we acquire and present $\sim 70 \mathrm{MHz}$ data from two temperate glaciers in the southwestern Swiss Alps having similar geological and climatic settings, but different bed sediment thicknesses and topographies: the Haut Glacier d'Arolla (HGdA) and the Glacier d'Otemma (GdO). Detailed 3-D processing and analysis of the amplitude characteristics of the GPR reflections from the glacier beds allow us to map the position of subglacial channels. Aerial imagery of the HGdA and drone-acquired imagery of the $\mathrm{GdO}$, acquired over two successive summers, along with the partial collapse of a snout marginal channel at the GdO site, provide validation of the GPR results. Maps of the Shreve hydraulic potential (Shreve, 1972) are also used for comparative purposes.

\section{Methodology}

\subsection{Field sites}

The HGdA and GdO are temperate valley glaciers located in the southwestern Swiss Alps (Fig. 1). The glaciers are separated by a distance of $\sim 3 \mathrm{~km}$. Due to their proximity, both glaciers have a similar climate forcing.

The HGdA is $3.3 \mathrm{~km}$ long and extends from 3500 to $2600 \mathrm{~m}$ a.s.l., with its terminus located at $45^{\circ} 58^{\prime} 58.366^{\prime \prime} \mathrm{N} / 7^{\circ}$ $31^{\prime} 24.979^{\prime \prime} \mathrm{E}$ in the summer of 2020 . The glacier initially flows from southeast to northwest from the Mont Brûlé, turning to flow from south to north toward the terminus. The subglacial hydrology of the HGdA has been investigated extensively in the scientific literature (e.g. Hubbard and others, 1995; Nienow and others, 1996; Nienow and others, 1998; Mair and others, 2002a, 2002 b). For several years, the glacier has had two main subglacial outlet channels, located along the eastern side of the glacier terminus (Fig. 2). More recently, the sediment dynamics have also been studied (Swift and others, 2005; Perolo and others, 2019). The bedrock underlying the glacier is composed of schistose granites, gneiss and metagranitoides (Tranter and others, 2002; Geological Atlas of Switzerland, 2020). This is covered by a layer of sediment, which in most places is several decimeters thick (Mair and others, 2003). The ice volume of the HGdA in the year 1999 was estimated to be $0.25 \pm 0.07 \mathrm{~km}^{3}$ based on topographic data (Farinotti and others, 2009a, 2009b). By far the biggest part of the glacier volume is located below the equilibriumline altitude (ELA), meaning that the HGdA is highly sensitive to increases in average air temperature. Indeed, the tongue of the HGdA has retreated by more than $400 \mathrm{~m}$ in length over the past 20 years (Gabbud and others, 2016) and serves as a proxy for alpine glaciers at medium to low elevations having a proportionately small accumulation area. Such glaciers are expected to continue to retreat rapidly over the next few decades (Salzmann and others, 2012; Huss and others, 2010).

The much-less-studied $\mathrm{GdO}$ is $7 \mathrm{~km}$ long and extends from 3790 to $2500 \mathrm{~m}$ a.s.l., flowing from northeast to southwest from the summit of the Pigne d'Arolla, with its terminus located at $45^{\circ} 56^{\prime} 18.908^{\prime \prime} \mathrm{N} / 7^{\circ} 25^{\prime} 20.212^{\prime \prime} \mathrm{E}$ in the summer of 2020 . There are two active tributary glaciers: de Blanchen and du Petit Mont Collon. The bedrock underlying the glacier is composed of a mixture of metagranitoides and metagabbros (Geological Atlas of Switzerland, 2020). Field observations where the glacier has 
a

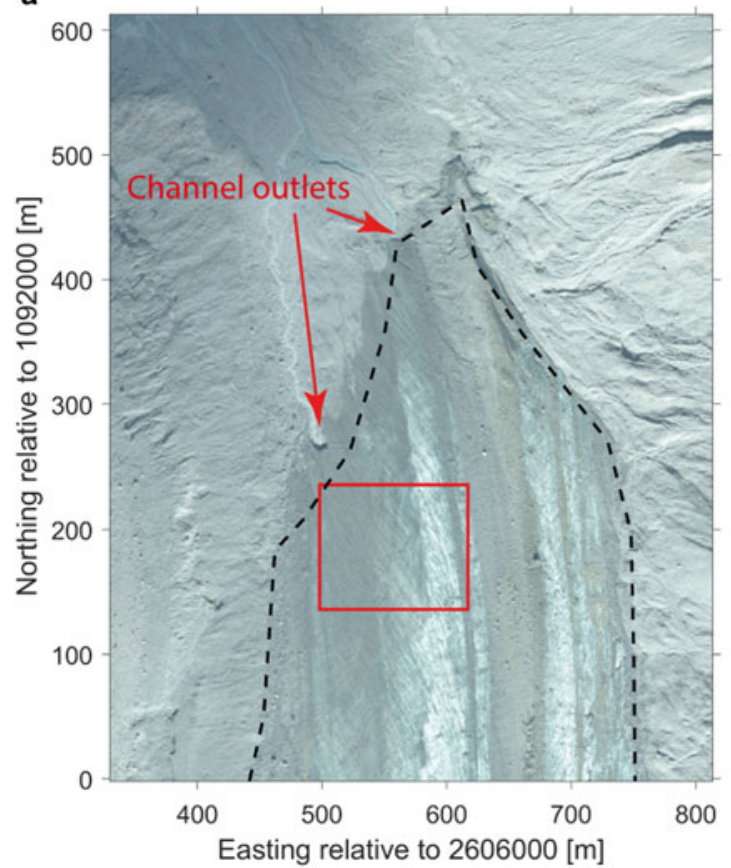

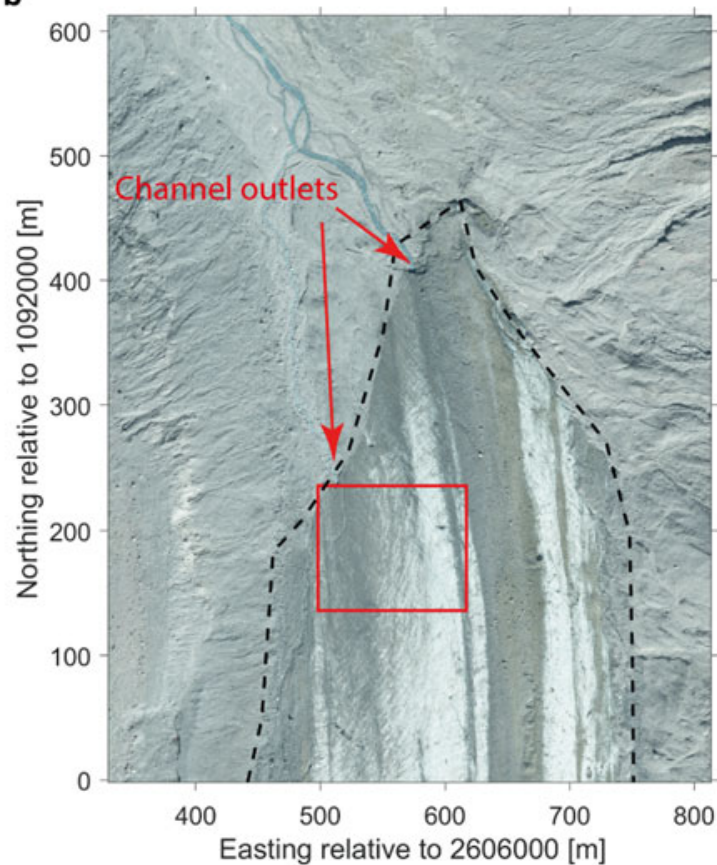

Fig. 2. Aerial orthoimagery of the tongue of the Haut Glacier d'Arolla taken in (a) September 2014 and (b) September 2015. The red square indicates the area over which high-density GPR measurements were acquired in August 2015. The GPR survey lines were oriented east-west. The dashed black line represents the most recent GLIMS glacier outline based on satellite imagery from 2015 (Paul and others, 2019).

recently receded show that this is typically covered by a thin layer of sediment, having a thickness of between a few centimeters and a few decimeters. The ice volume of the $\mathrm{GdO}$ was determined in 2009 to be $1.05 \pm 0.08 \mathrm{~km}^{3}$ based on airborne GPR and topographic data (Farinotti and others, 2009b; Gabbi and others, 2012). Since, similar to the HGdA, most of the glacier volume is currently located below the ELA, the GdO is sensitive to increases in average air temperature and has been retreating rapidly at an average rate of $40 \mathrm{~m}$ in length per year over the past 60 years (GLAMOS, 1881-2019).

\subsection{GPR measurements}

Zero-offset, high-density GPR data were acquired on both the HGdA and GdO using a lightweight, real-time-sampling GPR instrument manufactured by Radarteam, Sweden. The single transmitter-receiver antenna employed for the surveys has a nominal center frequency in air of $\sim 70 \mathrm{MHz}$ with a bandwidth between 20 and $140 \mathrm{MHz}$. To maximize portability, the GPR system was suspended from a backpack with the antenna located 0.4 $\mathrm{m}$ above the ground, which was found to provide good antenna coupling and a measurement quality that was virtually the same as that obtained with the antennas located directly on the ice surface. Data were collected on foot following parallel lines that were spaced either 1- or 2-m apart. GPR traces were recorded continuously at a frequency of $\sim 3.5 \mathrm{~Hz}$ using a time-sampling interval of $3.125 \mathrm{~ns}$, the latter of which was sufficient to avoid temporal aliasing. The system has a fixed scan time of $1600 \mathrm{~ns}$, which corresponds to a depth of investigation of $\sim 134 \mathrm{~m}$ assuming a radar wave speed in glacier ice of $0.167 \mathrm{~m} \mathrm{~ns}^{-1}$ (Murray and others, 2000). In the current study we focus on areas where the ice thickness was $<60 \mathrm{~m}$.

GPR lines spaced 1-m apart were surveyed over a $120 \mathrm{~m} \times 100$ $\mathrm{m}$ region of the snout marginal zone of the HGdA in August 2015 (Fig. 2). On the $\mathrm{GdO}$, an $\sim 200 \mathrm{~m} \times 100 \mathrm{~m}$ region was surveyed using a 2-m line spacing in August 2017 (Fig. 3). Over the latter period, a 200-m-long GPR line was also repeatedly measured over
24 h (hourly from 7 a.m. to 9 p.m. and every 3 h from 9 p.m. to 6 a.m.) in order to investigate the repeatability of the measurements over the course of a summer day (Fig. 3). Although previous work has suggested that radar velocity, attenuation and reflectivity in porous near-surface ice may vary strongly because of changing water content (Kulessa and others, 2008), no significant changes in the positions of the glacier bed or other major reflectors were detected, and relative reflection amplitudes remained stable (Figs S1 and S2 in Supplementary material). The influence of the orientation of the GPR antenna on the detectability of the glacier bed was also studied for the GdO (Langhammer and others, 2017), with results suggesting that GPR survey lines are best run perpendicular to ice flow with the radar antenna oriented perpendicular to the line direction. We adopted the latter strategy when acquiring the GPR data in this study, meaning that the parallel survey lines were oriented east-west at the HGdA, and northwest-southeast at the GdO.

For the GPR surveys on both the HGdA and the GdO, accurate positioning was achieved along each profile line using real-time dGPS navigation. A dGPS base station was installed at both sites close to the glacier terminus. Two operators were used to collect the GPR data, each of whom carried a dGPS rover antenna. One operator walked ahead and navigated along a preprogrammed path, whereas the other followed with the GPR system. The position of the GPR antenna was logged at a frequency of $10 \mathrm{~Hz}$ in order to provide GPS coordinates for each recorded trace with $\sim \pm 10 \mathrm{~cm}$ precision. GPR survey lines were found to deviate from the pre-programmed paths by no more than $25 \mathrm{~cm}$.

\subsection{Data processing}

Processing of the data from the HGdA and the GdO consisted of an initial series of steps to obtain a migrated 3-D GPR data volume, which was followed by picking and attribute analysis of the reflection from the glacier bed in order to identify subglacial channels. Note that, in general, such channels are not easily seen on the individual GPR profile lines because of the limited 


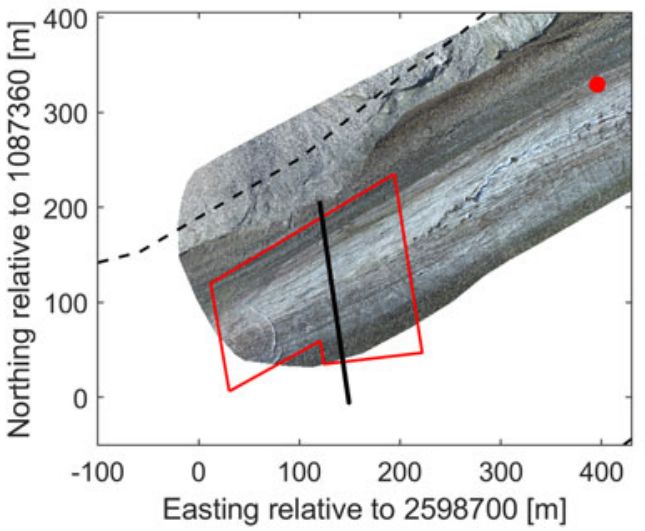

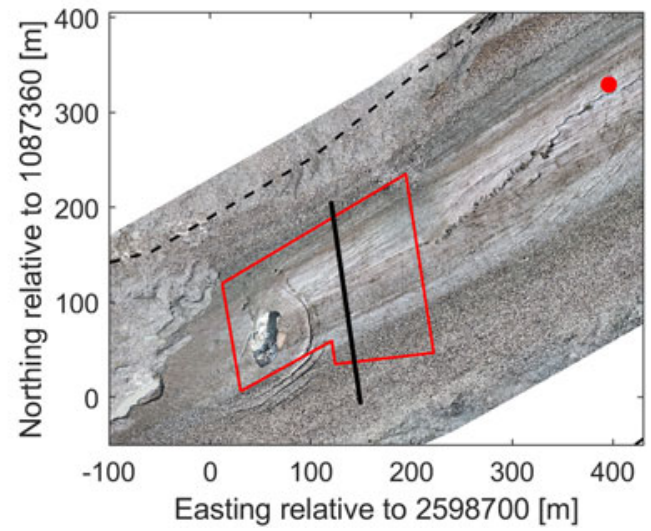

Fig. 3. Drone-based orthoimagery of the tongue of the Otemma glacier taken in (a) August 2017 and (b) August 2018. The red polygon indicates the area over which high-density 3-D GPR measurements were acquired in August 2017. The GPR survey lines were oriented northwest-southeast. The black line indicates the location of the GPR repeat profile analyzed in the Supplementary material (Figs S1 and S2). The red dot displays the location of a moulin. The region not covered by the drone survey is indicated in white. The dashed black line represents the most recent GLIMS glacier outline based on satellite imagery from 2015 (Paul and others, 2019).

Table 1. Initial processing steps applied to the 3-D GPR data

\begin{tabular}{|c|c|c|}
\hline $\begin{array}{l}\text { Step } \\
\text { number }\end{array}$ & Activity & Description \\
\hline 1 & GPS data cleaning & $\begin{array}{l}\text { Remove clearly erroneous GPS coordinates and replace them with interpolated coordinates such that each GPR trace has } \\
\text { an accurate horizontal and vertical position. }\end{array}$ \\
\hline 2 & GPR data binning & $\begin{array}{l}\text { Bin the GPR data to create a regular }(0.2 \mathrm{~m}) \text { trace spacing along the lines by assigning the closest GPR trace to each cell of } \\
\text { a predefined grid. Each GPR survey line was binned separately, which was possible because of the limited deviation of the } \\
\text { true line coordinates from their theoretical positions thanks to real-time dGPS navigation. }\end{array}$ \\
\hline 3 & $\begin{array}{l}\text { Acquisition pattern } \\
\text { correction }\end{array}$ & $\begin{array}{l}\text { Correct for a systematic spatial offset between survey lines run in opposite directions, related to small errors in timing and } \\
\text { the angle of the dGPS rover antenna. This was done by finding the constant position shift between lines run in opposite } \\
\text { directions that maximized the line-to-line correlation }(0.4 \mathrm{~m}) \text {. }\end{array}$ \\
\hline 4 & Time zero correction & $\begin{array}{l}\text { Adjust the zero time of the GPR recordings such that the time on each trace accurately represents the two-way travel time. } \\
\text { Calibration tests involving suspending the GPR antenna from a known height have indicated that a correction of }-25 \mathrm{~ns} \text { is } \\
\text { necessary for our system. }\end{array}$ \\
\hline 5 & Trace normalization & $\begin{array}{l}\text { Normalize each trace in the dataset by its maximum amplitude in order to correct for varying coupling between the GPR } \\
\text { instrument and the glacier surface. }\end{array}$ \\
\hline 6 & Mean trace removal & $\begin{array}{l}\text { Subtract the mean trace determined over a sliding 30-trace window, only in the upper part of the GPR section from } 0 \text { to } \\
175 \mathrm{~ns} \text {, in order to remove the emitted GPR pulse from the dataset. }\end{array}$ \\
\hline 7 & De-wow filter & Remove low-frequency 'wow' superimposed upon the reflection data using a 13-point residual median filter. \\
\hline 8 & Gain & $\begin{array}{l}\text { Boost signal amplitudes using a single, smooth, time-varying gain function that is derived from the inverse average } \\
\text { absolute amplitude decay curve in the dataset. This is used to compensate for losses due to geometrical spreading, } \\
\text { attenuation and scattering without imposing any spatial amplitude trends upon the data that could be misinterpreted in } \\
\text { our analysis. }\end{array}$ \\
\hline 9 & Trace interpolation & $\begin{array}{l}\text { Reduce the time-sampling interval along each trace to } 0.7812 \mathrm{~ns} \text { using Fourier interpolation in order to quadruple the } \\
\text { number of points per trace for improved display, migration and analysis. }\end{array}$ \\
\hline 10 & Time migration & $\begin{array}{l}\text { Perform 3-D topographic time migration using the algorithm of Allroggen and others (2015), which is based on the general } \\
\text { Kirchhoff scheme presented in Schneider (1978). A constant migration velocity of } 0.16 \mathrm{~m} \mathrm{~ns}^{-1} \text { and migration aperture of } 10 \\
\mathrm{~m} \text { were utilized, which were found to effectively collapse diffraction hyperboloids in the data. }\end{array}$ \\
\hline 11 & Time-to-depth conversion & Convert time-migrated GPR section to depth using the same constant velocity of $0.16 \mathrm{~m} \mathrm{~ns}^{-1}$. \\
\hline 12 & Topographic correction & $\begin{array}{l}\text { Move traces vertically according to the measured topography by applying a linear Fourier phase shift, which allows for } \\
\text { trace adjustment by a fractional number of time samples. }\end{array}$ \\
\hline
\end{tabular}

vertical resolution of the data. That is, for our $70-\mathrm{MHz}$ antenna with a dominant radar wavelength in ice of over $2 \mathrm{~m}$, it is generally not possible to image separately the channel roofs and floors and thus unambiguously identify these features (Fig S3 in Supplementary material), in particular if the channels are at least partially air-filled. However, as the channels represent a strong contrast in radar reflection coefficient compared to their surroundings, they can be imaged via amplitude analysis along the bed. All processing was done in the MATLAB computing environment using customized codes. Table 1 summarizes the initial steps carried out on the data. During the GPR data acquisition, the dGPS rover antenna logging the GPR instrument position experienced occasional drops in precision leading to local shifts in recorded elevation which had to be manually removed and replaced using linear interpolation. An acquisition pattern adjustment of $0.4 \mathrm{~m}$ was also necessary between GPR lines run in opposite directions (i.e. a position shift of $0.2 \mathrm{~m}$ in each direction) in order to correct for positioning errors related to system timing delays and the angle of the GPS rover antenna.

Figure 4 shows the results of applying the processing steps described in Table 1 to a single east-west GPR survey line from the HGdA dataset collected along $1092150-\mathrm{m}$ northing. In Figure $4 \mathrm{a}$, we see that the GPS-corrected and binned raw data do not allow for easy identification of subglacial structure due to the presence of: (i) the emitted GPR pulse; (ii) unwanted low frequencies ('wow') upon which the GPR reflections are superimposed and (iii) amplitude variations due to signal attenuation and differences in antenna coupling. After amplitude normalization, removal of the emitted pulse, dewow, gain and time interpolation (Fig. 4b), the data become easier to interpret but are still 


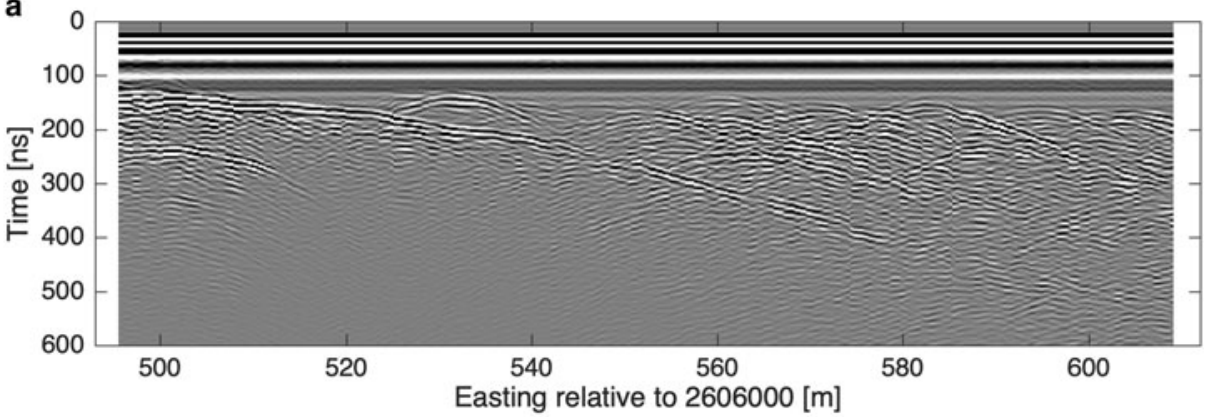

b
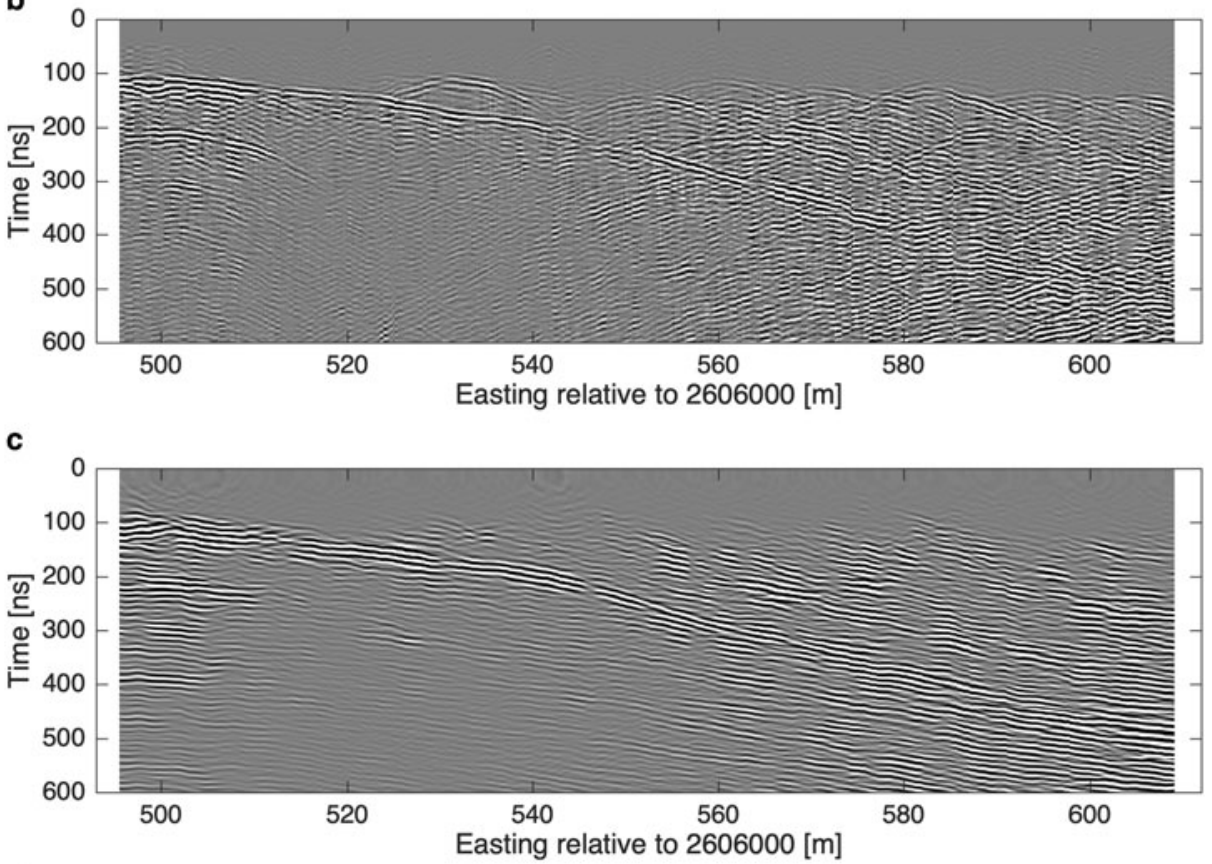

d

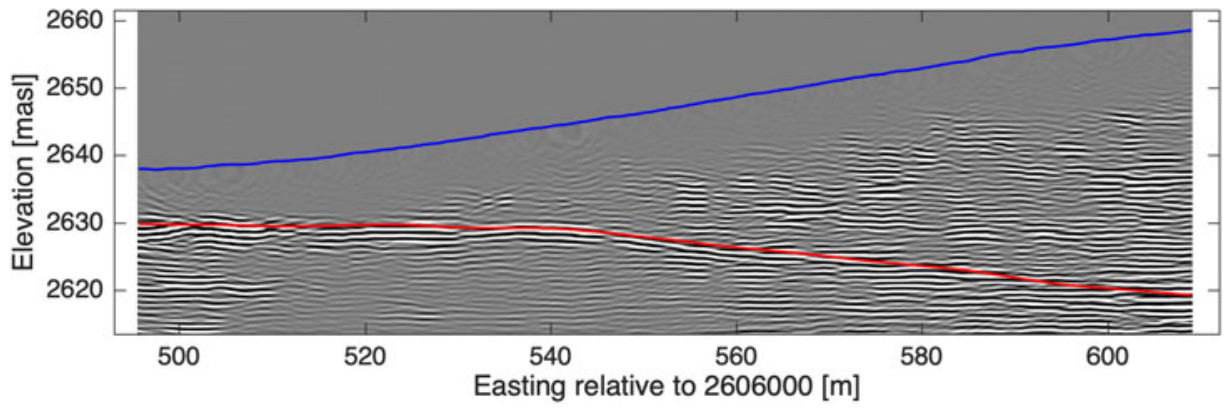

Fig. 4. Demonstration of the GPR processing described in Table 1 for one east-west survey line from the HGdA acquired along $1092150 \mathrm{~m}$ northing: (a) binned and time-zero-corrected raw data (steps 1-4); (b) after trace normalization, direct arrival removal, dewow, gain and trace interpolation (steps 5-9); (c) after subsequent 3-D topographic Kirchhoff time migration (step 10) and (d) after time-to-depth conversion and correcting for topography (steps 11 and 12). The blue line shows the ice surface whereas the red line indicates the picked glacier bed reflection. contaminated by numerous hyperbolic diffraction events related to the presence of small scatterers (water pockets, air voids and boulders) within the ice. Figure $4 \mathrm{c}$ shows the result of 3-D topographic time migration using the algorithm of Allroggen and others (2015) with a migration aperture of $10 \mathrm{~m}$ and assuming a constant radar wave velocity of $0.16 \mathrm{~m} \mathrm{~ns}^{-1}$. The latter value was found to provide the best collapse of diffraction hyperboloids in the 3-D volume and is appropriate for temperate ice (Plewes and Hubbard, 2001; Murray and others, 2007). Finally, Figure $4 \mathrm{~d}$ shows the final GPR image after time-to-depth conversion and topographic correction, where we see in blue and red the glacier surface topography and position of the bed, respectively.

After the initial processing described above, the migrated 3-D GPR image was analyzed to quantify the amplitude characteristics of the reflection along the glacier bed. Subglacial channel locations are expected to correspond with anomalously high bed reflection amplitudes because they represent a strong contrast in dielectric permittivity (e.g. ice/air or ice/water) compared to their surroundings (e.g. ice/bedrock) (Wilson and others, 2014; Church and others, 2019). To this end, we first performed a manual line-by-line picking of the glacier bed reflection (Fig. 4d), the results of which were used to fit a thin plate smoothing spline to the glacier bed surface. For the HGdA, the mean deviation between this modeled surface and the glacier-bed picks was $0.27 \mathrm{~m}$. For the GdO, it was $0.39 \mathrm{~m}$. Next, the 3-D GPR image was 'flattened' along the modeled bed surface by applying a linear Fourier phase shift to each trace, the latter of which allowed us to conform the data smoothly to the picked bed topography. Although not essential for the amplitude analysis described below, flattening the data in this manner greatly facilitated the extraction of bed reflection profiles, in the sense that they could be obtained by slicing horizontally through the 3-D data matrix. Next, we calculated the magnitude of the Hilbert transform of each trace (i.e. the so-called 'instantaneous amplitude'), which provides the trace amplitude envelope and is commonly used in seismic data processing to quantify reflection strength (e.g. 


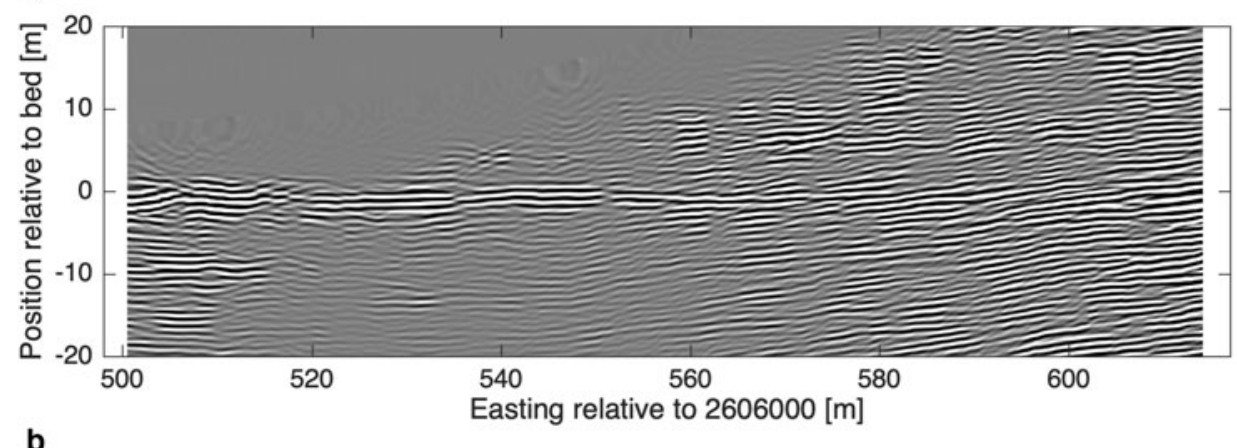

b

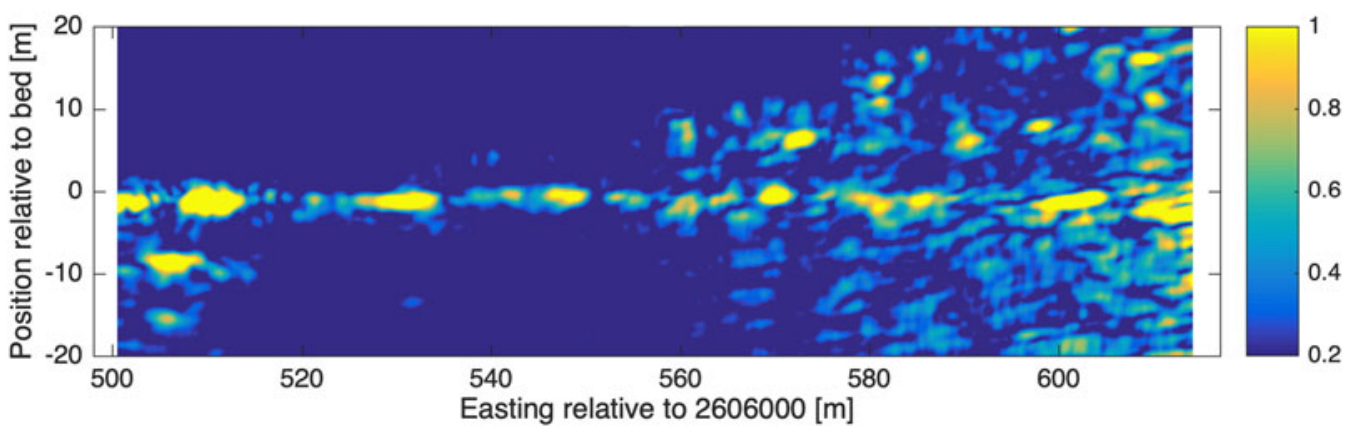

Fig. 5. Illustration of our amplitude analysis of the glacier bed reflection: (a) processed GPR survey line from Figure 4d 'flattened' to the bed reflection event and (b) corresponding normalized absolute value of the Hilbert transform along each trace, which quantifies reflection strength.

Taner and others, 1979). Finally, the maximum of this result was computed over a small $(2-\mathrm{m})$ window containing the bed reflection in order to compensate for any errors in our determination of the precise location of the bed. The resulting 2-D map of maximum reflection strength along the glacier bed can be examined for spatial patterns indicative of subglacial channels.

In Figure 5, we show the application of our amplitude processing to the single GPR profile from the HGdA dataset presented in Figure 4. Figure $5 \mathrm{a}$ shows the GPR image from Figure $4 \mathrm{~d}$ after flattening the data to the picked glacier bed surface. In Figure 5b, we plot the absolute value of the Hilbert transform, where a strong increase in reflection strength around the location of the bed can be seen. Note, however, that the distribution of amplitudes along the bed is highly non-uniform due to the variability in reflectivity at this interface. An image plot of the maximum instantaneous amplitude over a small window containing the bed reflection, for all of the survey lines in the 3-D dataset, is used to identify coherent trends related to the presence of subglacial channels. These latter results are presented and described in Sections 3.1 and 3.2 for the HGdA and GdO datasets, respectively.

\subsection{Validation of results}

The results of our analysis were assessed using two different strategies. The first one involved comparison with aerial orthoimagery acquired at some time after the GPR surveys, where it was possible to either see directly the investigated subglacial channels, or evidence thereof, due to glacier retreat and ice-marginal breakup. At the HGdA, although glacier retreat between 2014 and 2015 was rapid ( $30 \mathrm{~m}$ in length), it was not enough to reveal directly the channels identified with GPR. However, we could compare our results with the location of subglacial channels exiting the glacier snout in 2014 and 2015. Ortho-rectified aerial imagery acquired by Flotron SA in two consecutive years (September 2014 and September 2015) also indicated the development of two large fractures on the HGdA surface within 1 month of our GPR survey. These were later verified in the field to be places where the ice ruptured, which we believe occurred due to instabilities related to surface melting and the enlargement of marginal subglacial channels below. At the GdO, drone imagery was acquired in August 2017 and August 2018 using DJI Phantom 3 and Phantom 4 drones, respectively. The corresponding orthoimages documented the collapse of a large portion of the main outlet channel in the summer of 2018 along with rapid glacier retreat, which provided direct validation of the GPR findings $\sim 1$ year after the measurements.

As a second validation method, we estimated the hydraulic potential at the glacier bed (Shreve, 1972) in order to predict the theoretically most likely trajectories of subglacial channels. This was done by summing contributions to the potential related to elevation and ice overburden pressure as follows:

$$
\varphi=\rho_{\mathrm{w}} g z+c\left(\rho_{\mathrm{i}} g(H-z)\right)
$$

where $\varphi$ is the hydraulic potential, $\rho_{\mathrm{w}}=1000 \mathrm{~kg} \mathrm{~m}^{-3}$ is the density of water, $g=9.81 \mathrm{~m} \mathrm{~s}^{-2}$ is the acceleration of gravity, $z$ is the glacier bed elevation, $\rho_{\mathrm{i}}=910 \mathrm{~kg} \mathrm{~m}^{-3}$ is the density of ice, $H$ is the ice surface elevation and $c$ is a constant that accounts for the degree of pressurization of the channels. A value of $c=0$ represents unpressurized flow, whereas a value of $c=1$ represents fully pressurized flow where the ice overburden pressure significantly influences the hydraulic gradient and thereby the flow paths. Ice surface topography data for the HGdA and GdO were obtained from the SwissAlti3D Digital Elevation Model for the summers of 2012 and 2009, respectively (SwissTopo, 2020). These data have horizontal and vertical resolutions of $2 \mathrm{~m}$ and were derived from aerial imagery. Glacier bed elevations for the HGdA at 20-m horizontal resolution, derived from irregularly spaced GPR surveys, were supplied by Dr Ian Willis at the University of Cambridge (Sharp and others, 1993). For the GdO, bed elevations at 50-m horizontal resolution were obtained from Dr Mauro Werder at ETH Zurich and derived from helicopter-borne GPR surveys conducted in 2009 (Gabbi and others, 2012). Considerations by Hooke (1984) show that, given high enough discharge and bed slope, especially when ice thicknesses are small (i.e. $<50 \mathrm{~m}$ ), the flow in subglacial 

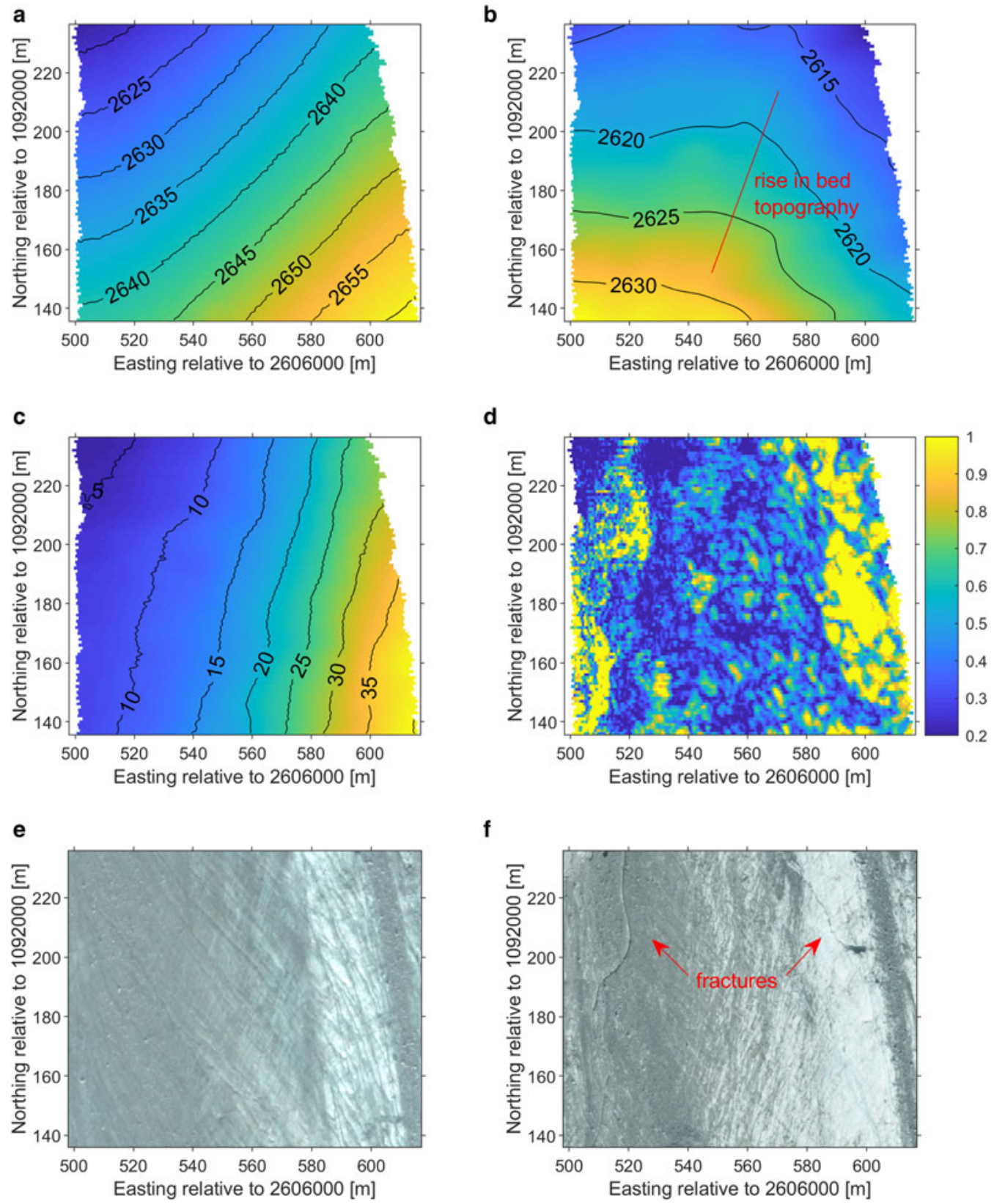

Fig. 6. GPR data analysis results for the HGdA site: (a) glacier surface elevation ( $m$ a.s.l.); (b) glacier bed elevation ( $m$ a.s.l.); (c) ice thickness (m); (d) maximum normalized reflection strength along the glacier bed; (e) zoom of September 2014 orthophoto from Figure 2a and (f) zoom of September 2015 orthophoto from Figure $2 b$.

channels may not be pressurized. It is also unlikely that such channels close during winter due to insufficient ice overburden weight. Channel positions, however, may be inherited from when they formed under deeper ice in pressurized conditions. As these aspects remain uncertain, we apply Eqn (1) using values of $c=0, c=0.5$ and $c=1$ in our analysis.

The gradient of the Shreve potential yields the local flow direction, which is used to compute flow accumulation and estimate the most likely subglacial flow pathways. The latter was done using the Topotoolbox package in MATLAB (Schwanghart and others, 2013; Schwanghart and Scherler, 2014). To form a channel feature, flow accumulation thresholds of 180 upstream cells for the HGdA (cell size $20 \mathrm{~m} \times 20 \mathrm{~m}$ ) and 60 upstream cells for the GdO (cell size $50 \mathrm{~m} \times 50 \mathrm{~m}$ ) were considered. These values are different for each glacier because of the different sizes of the bed topography grid cells in each case; a lower number of larger cells is needed to achieve the same amount of flow as when using smaller cells. Note that the computed channel features reflect the hydraulic conditions according to the Shreve potential at the times when the SwissAlti3D DEMs for each glacier were acquired, which are not the same as the acquisition dates of the GPR datasets. However, given the fact that neither the overall surface topography nor the contributing areas of each glacier changed substantially between the DEM and GPR acquisitions, we do not expect a significant change in the predicted subglacial channel locations. Therefore, the considered DEM and bed topography datasets and resulting Shreve calculations provide the best available theoretical insight into the hydraulic potential underneath the two glacier tongues for comparison with our GPR data.

\section{Results}

\subsection{Haut glacier d'Arolla}

In Figure 6, we present the results of our analysis of the HGdA GPR dataset. Figure 6a shows the measured ice surface topography over the GPR survey region. The local slope of the glacier 
surface can be seen to be approximately constant and is oriented toward the northwest. In Figure 6b, we plot the GPR-derived glacier bed topography. Unlike the ice surface topography, the glacier bed is seen to slope toward the north in the western half of the profile and toward the northeast in the eastern half of the profile, with a faint rise separating these two regions. Figure $6 \mathrm{c}$ shows the calculated ice thickness over the survey region, which was obtained by subtracting the elevations in Figure $6 \mathrm{~b}$ from those in Figure 6a.

Here, we observe that the ice thickness decreases both in the direction of the glacier terminus toward the north, as well as strongly toward the western edge of the glacier where thinning is more significant. The eastern part of the zone of interest has more bare ice whose higher albedo leads to less melting in this region. Further east outside of the GPR survey region, a morainic debris cover of up to several decimeters thick reduces melting due to insulation (Fig. 2b).

Figure $6 \mathrm{~d}$ shows the maximum absolute value of the Hilbert transform of the GPR data in the location of the glacier bed for the HGdA dataset, which again quantifies the reflection strength. In this image, higher values are expected to correspond with the location of subglacial channels due to a stronger contrast in dielectric permittivity. We see in the figure that there are two main zones where the amplitude increases significantly; one with small bends on the western side of the survey grid and another primarily linear zone on the eastern side. Both of these zones are oriented approximately north-south and measure several meters in width. The fact that they show continuity perpendicular to the direction of the GPR survey lines (which were run east-west) suggests that they are not artifacts of the data acquisition or processing, but rather represent real differences in GPR bed reflectivity. The western-most zone ends at the glacier terminus at a channel outlet (Fig. 2) and is aligned with the topographic gradient of the bedrock topography (Fig. 6b). It is situated in a region of shallow ice having a thickness of $<15 \mathrm{~m}$. The zone on the eastern side, on the other hand, is located in region having ice thickness between 20 and $35 \mathrm{~m}$. It is wider and appears to be associated with a higher bed reflectivity, and may represent a subglacial channel that continues toward the northeast, ending at the second, eastern channel outlet (Fig. 2). Both zones are separated by the rise in bed topography near the center of the glacier tongue (Fig. $6 \mathrm{~b}$ ).

Figures $6 \mathrm{e}$ and $6 \mathrm{f}$ show zooms of the orthoimages from Figures $2 \mathrm{a}$ and $2 \mathrm{~b}$ over the GPR survey region, respectively. The image in Figure 6e was acquired in September 2014, and reflects quite well the conditions of the glacier surface when the GPR data were acquired in August 2015, aside from some recession near the glacier terminus. The image in Figure $6 \mathrm{f}$, on the other hand, was acquired in September $2015 \sim 1$ month after the GPR acquisition. Here, we see that two notable fractures have developed on the glacier surface in the western and eastern parts of the survey region, which were not present during the GPR survey. A subsequent visit to the HGdA in October 2015 confirmed that the ice ruptured in these locations and that the fractures continued all the way to the glacier bed, where the sound of rushing water could be heard. With regard to the western-most fracture, we observe that its overall trend is remarkably similar to that of the western zone of increased reflection amplitude in Figure 6d. This suggests that the fracture represents the beginning of the collapse of unstable ice over a shallow subglacial channel, and that the GPR survey allowed for detection of this channel before the fracturing occurred. With regard to the eastern-most fracture, we see that it loosely corresponds to a region of high reflectivity in roughly the same location (Fig. 6d), which suggests that it may represent a small branch of the larger eastern-most subglacial channel that has ruptured to the surface.
Figure 7 shows the results of our Shreve hydraulic potential analysis for the HGdA site, which was performed over a broad region encompassing the entire glacier tongue (Fig. 7a). In Figure $7 \mathrm{~b}$ we plot the Shreve potential computed for $c=0$ in Eqn (1), which corresponds to the case of unpressurized (openchannel) flow. The main drainage pathways obtained via flow accumulation, as well as the suspected channel locations digitized from the GPR results in Figure 6d, are shown as red and yellow lines, respectively. Similarly, Figures $7 \mathrm{c}$ and $7 \mathrm{~d}$ plot the results obtained for values of $c=0.5$ (partially pressurized flow) and $c$ $=1$ (fully pressurized flow). We observe that the GPR-derived channel locations correspond well with the Shreve hydraulic potential scenarios for unpressurized and partly pressurized flow, although the best correspondence would result from a combination of these two scenarios. The location of the western channel also corresponds to the Shreve hydraulic potential for fully pressurized flow. In the location of the GPR survey, the glacier ice was relatively shallow with a maximum thickness of $45 \mathrm{~m}$, which suggests that pressurized flow there is unlikely. Further upstream, however, the flow may be (or have been) pressurized several years ago due to greater ice thicknesses, which may have established the channels in their present positions (Sharp and others, 1993), explaining the current location of channels further downstream. Also note that the Shreve potential was computed based on glacier surface elevation data from 2012, whereas the GPR data were recorded in 2015 , which may account for some of the differences between the two results.

\subsection{Glacier d'Otemma}

In Figure 8, we present the results of our analysis of the GdO GPR dataset. Figures $8 \mathrm{a}, 8 \mathrm{~b}$ and $8 \mathrm{c}$ show the measured ice surface topography, GPR-derived glacier bed elevations and calculated ice thickness over the survey region, respectively. All of these are superposed on a drone orthophoto from August 2018. We see in the figure that the local surface topography slopes uniformly toward the glacier terminus, but on the lower part of this slope there is a slight surface depression which was developing into a channel collapse at the time of the GPR survey. Compared to the HGdA, the bed topography at the GdO is relatively flat over most of the survey region, with the exception of a $\sim 3$-m-deep depression toward the northeast. Toward the southern edge of the survey area, there are strong increases in the elevation of both the glacier bed and the ice surface, which are related to the valley's U-shape and reduced melting in this location due to the large amount of debris cover. The ice thickness is seen to follow the commonly observed pattern of decreasing toward the glacier terminus, and is roughly constant across the glacier width with the exception of the zone near the terminus associated with the developing channel collapse.

Figure $8 \mathrm{~d}$ shows the maximum absolute value of the Hilbert transform of the GPR data in the location of the glacier bed for the GdO dataset. In contrast to the HGdA, we see that there is a single clear zone showing a strong increase in reflection strength that extends across the entire GPR survey region. This zone, which we believe represents a large subglacial channel, appears to be up to $10 \mathrm{~m}$ in width. It originates in the east near the center of the glacier, makes a turn toward the northern boundary of the survey region, and then continues along the northern glacier margin before making a relatively sharp turn back toward the center of the glacier. The latter trajectory appears logical in the sense that it tends to avoid the higher areas of the bedrock topography (Fig. 8b). Similar to the HGdA, the fact that the high-amplitude region shows continuity perpendicular to the direction of the GPR survey lines (which were run roughly south-north) indicates 

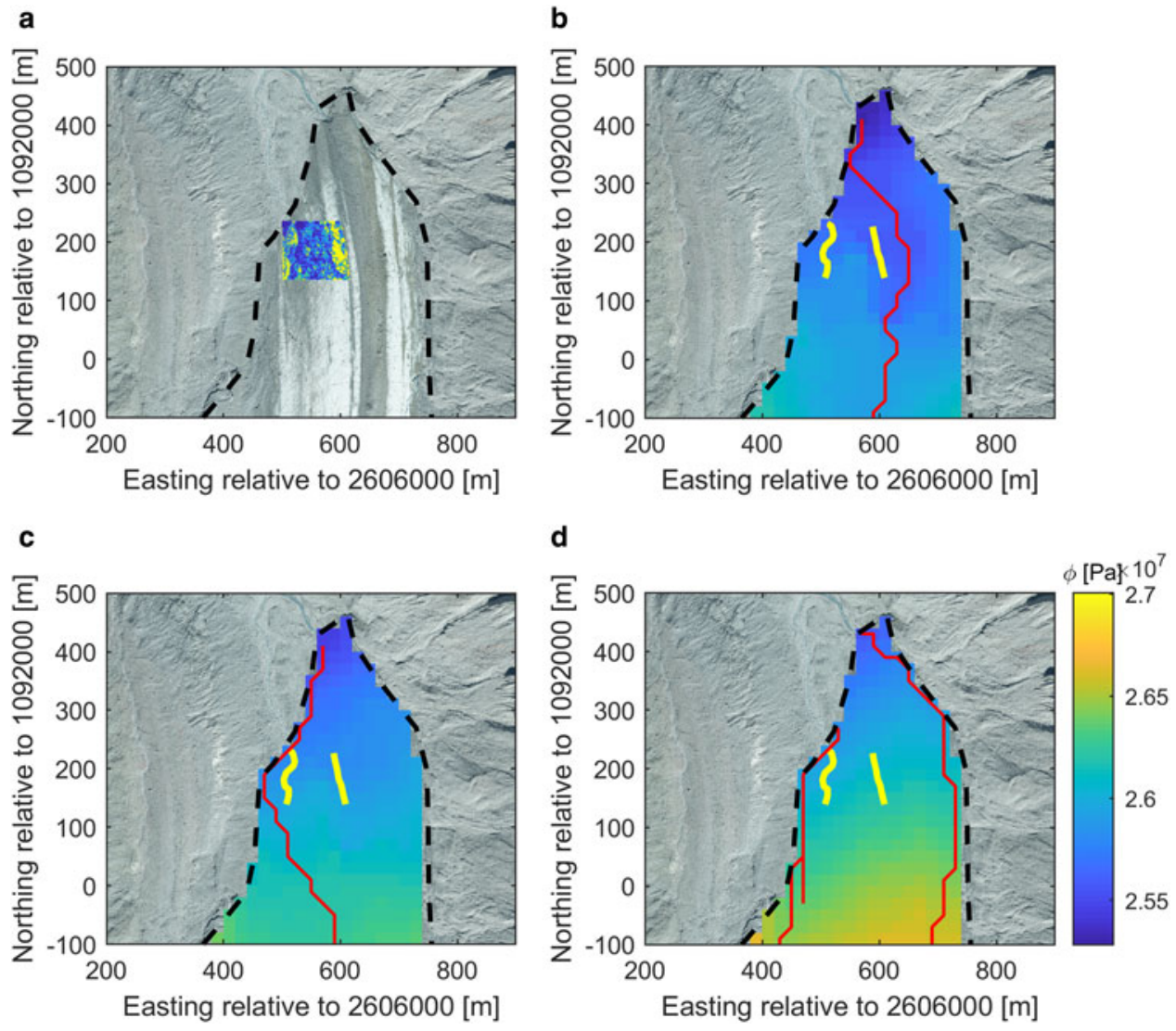

Fig. 7. (a) Zoom of September 2015 orthophoto from Figure $2 b$ in the region of the tongue of the HGdA, upon which the GPR amplitude analysis results from Figure $6 \mathrm{~d}$ are superposed; (b-d) calculated Shreve hydraulic potential along with the theoretically most likely flow paths (red lines) and the manually digitized GPR-derived subglacial channel positions (yellow lines). The Shreve hydraulic potential is presented for (b) open-channel flow ( $c=0$ ); $(c)$ partly pressurized flow $(c=0.5)$ and $(d)$ fully pressurized flow $(c=1)$. The dashed black line represents the GLIMS glacier outline for the summer of 2015 (Paul and others, 2019 ).

that it is not an artifact of the data acquisition or processing, but rather reflects real differences in bed reflectivity.

Figures $8 \mathrm{e}$ and $8 \mathrm{f}$ show zooms of the orthophotos presented in Figures $3 \mathrm{a}$ and $3 \mathrm{~b}$, respectively. The image in Figure $8 \mathrm{e}$ was acquired in August 2017 during the acquisition of the GPR data, whereas the image in Figure $8 \mathrm{f}$ was acquired $\sim 1$ year later. Between these acquisition dates, the $\mathrm{GdO}$ retreated by $\sim 40 \mathrm{~m}$ on its northern side. A large portion of the region surveyed in 2017 also collapsed sometime between mid-July 2018 and early August 2018, revealing a cavity $\sim 60-\mathrm{m}$ long, $20-\mathrm{m}$ wide and $10-\mathrm{m}$ deep. The position of this cavity coincides well with the suspected subglacial channel location from Figure 8d, and we believe that surface downwasting combined with channel melting from the inside led to the ice becoming unstable. We also see in Figure $8 \mathrm{f}$ that the channel enters from the northeast into the collapsed area and continues toward the south before turning westward out of the collapsed area, which is consistent with the GPR results in Figure 8d. Note that collapse of the channel roof during the autumn of 2018 was observed in the field and confirms the channel outflow and inflow positions downstream and upstream of the collapsed section in Figure 8f, respectively. Finally, a moulin was detected further upstream of the main channel (Fig. 3), whose location may provide further validation for the location of the subglacial channel.

Figure 9 shows the results of our Shreve hydraulic potential analysis for the GdO site, which, like the HGdA, was performed over a broad region encompassing the entire glacier tongue (Fig. 9a). Figures 9b, 9c and 9d show the hydraulic potential calculated for $c$ values of $0,0.5$ and 1, respectively. The main drainage pathways obtained via flow accumulation, as well as the suspected channel location digitized from the GPR results in
Figure 8d, are again shown as red and yellow lines, respectively. We see that the three flow scenarios lead to reasonably similar drainage patterns that correspond quite well with the GPR results, except for the fact that they do not predict the meandering shape of the identified channel. This may be a result of the significantly lower $(50-\mathrm{m})$ resolution bed topography measurements used for the generation of the Shreve hydraulic potential maps in this case. Indeed, we believe that the meandering shape of the subglacial channel identified in the GPR results reflects strong bedrock control on flow at the GdO via local changes in bed topography and roughness (Alley, 1992; Gulley and others, 2014).

\section{Discussion}

\subsection{Substantive findings}

Marginal subglacial channels at the HGdA and GdO were mapped via amplitude analysis of the glacier bed reflection identified in high-resolution 3-D GPR data. The corresponding results were validated using aerial orthoimagery acquired after the GPR surveys, as well as calculation and analysis of the Shreve hydraulic potential. In the case of the HGdA, two subglacial channels were identified; a slightly tortuous one on the western side of the glacier tongue, and a second larger and more linear channel on the eastern side (Fig. 6d). At the GdO, one main, tortuous channel was detected (Fig. 8d), which follows the northern edge of the glacier tongue before turning toward the center of the glacier.

The locations of en- and subglacial channels within temperate alpine glaciers have been previously identified with GPR measurements. However, existing data were generally not acquired at high enough density for processing and analysis in $3-\mathrm{D}$, which here 


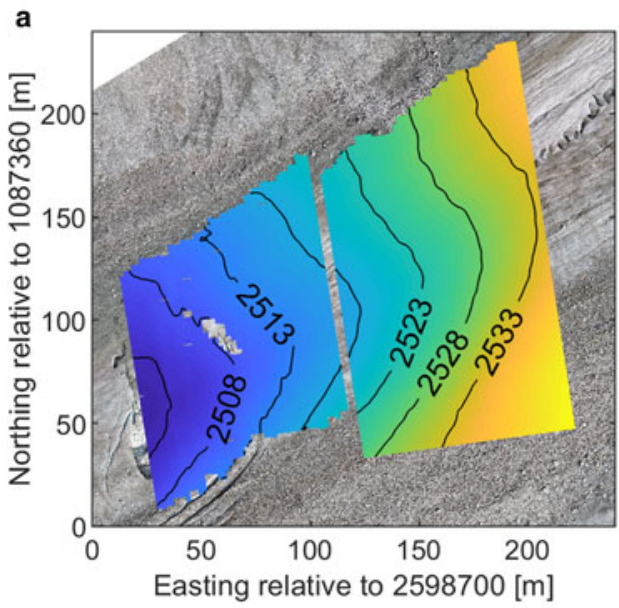

c

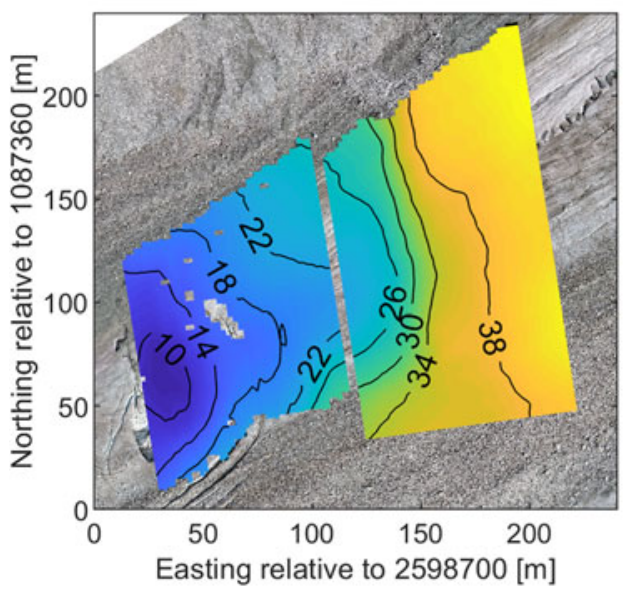

e

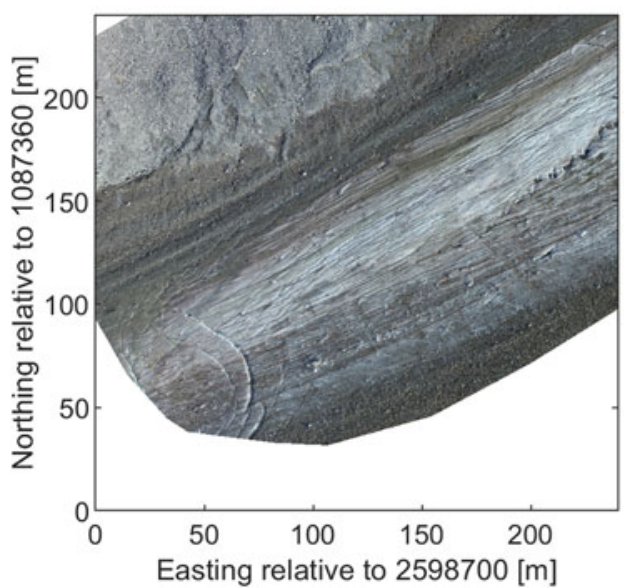

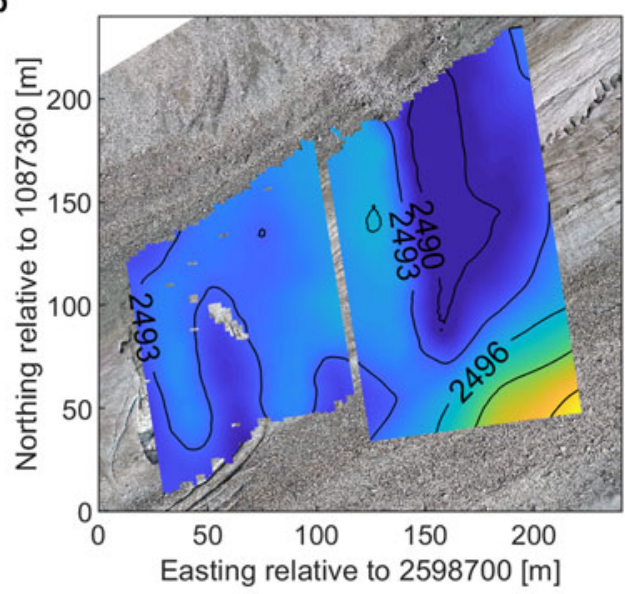

d

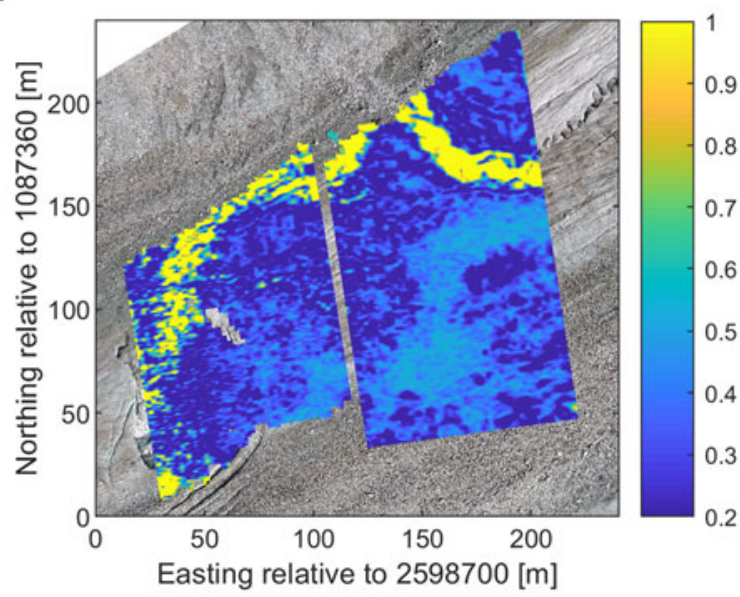

f

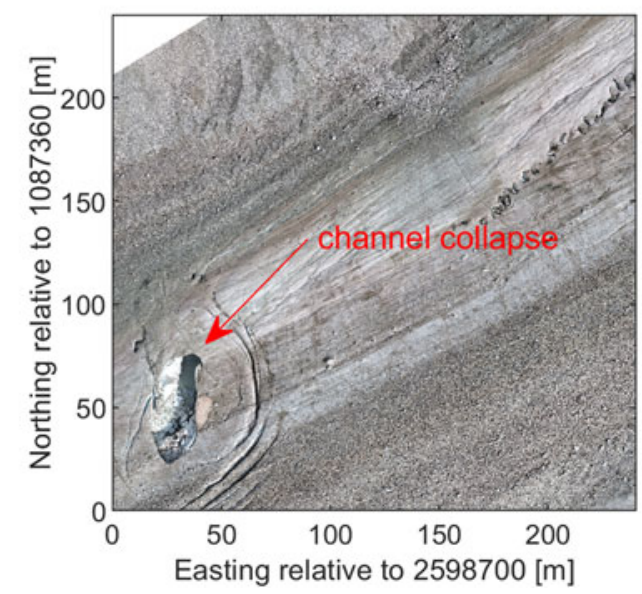

Fig. 8. GPR data analysis results for the GdO site: (a) glacier surface elevation ( $m$ a.s.l.); (b) glacier bed elevation ( $m$ a.s.l.); (c) ice thickness ( $m$ ); (d) maximum normalized reflection strength along the glacier bed; (e) zoom of August 2017 orthophoto from Figure 3a and (f) zoom of August 2018 orthophoto from Figure 3b.

allows for the mapping of subglacial channels continuously with meter-scale resolution. Indeed, past research has largely involved channel detection along 2-D GPR survey lines and subsequent interpolation of flow pathways when multiple line data were available (e.g. Bælum and Benn, 2011; Temminghoff and others, 2019). Our study, in contrast, focuses on analysis of the amplitude characteristics of the glacier bed reflection in order to create a detailed map of the suspected channel pathways. This also has the advantage of being able to detect channels that may not be easily seen as distinct reflections on individual GPR profiles.
Although the acquisition of such high-density GPR data for $3-\mathrm{D}$ analysis is highly laborious, in particular with regard to surveying areas much larger than those considered here on foot, recent technological developments in lightweight, real-time-sampling GPR instruments and drone-based sensing provide promise for carrying out such surveys over larger regions in an automated manner.

The western marginal subglacial channel detected beneath the HGdA (Fig. 6d) corresponds well with the position of a western channel outlet visible on the aerial orthoimages from both 2014 

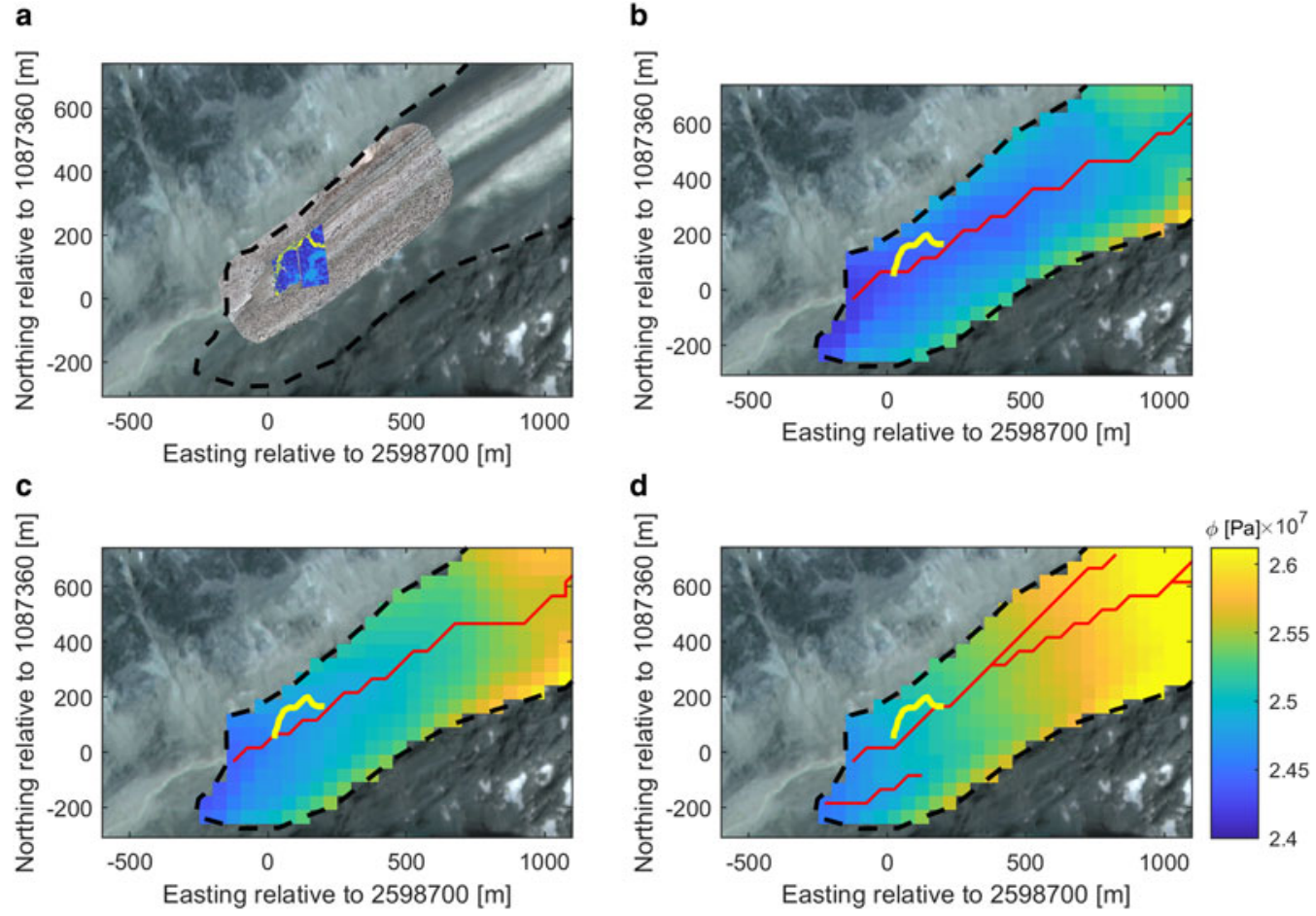

Fig. 9. (a) August 2018 orthophoto from Figure $3 \mathrm{~b}$ overlain on a 2019 satellite image in the region of the tongue of the GdO, upon which the GPR amplitude analysis results from Figure $8 \mathrm{~d}$ are superposed; (b-d) calculated Shreve hydraulic potential along with the theoretically most likely flow paths (red lines) and the manually digitized GPR-derived subglacial channel position (yellow lines). The Shreve hydraulic potential is presented for (b) open-channel flow ( $c=0$ ); (c) partly pressurized flow $(c=0.5)$ and $(d)$ fully pressurized flow $(c=1)$. The dashed black line represents the GLIMS glacier outline for the summer of 2015 (Paul and others, 2019 ).

and 2015 (Fig. 2), whereas the wider eastern channel appears to lead toward an eastern channel outlet. Previous subglacial hydrological studies noted two main flow pathways in this area of the HGdA glacier tongue (Sharp and others, 1993). Perhaps most importantly, fractures appearing on the glacier surface $\sim 1$ month after the GPR data acquisition (Fig. 6f) follow closely the western subglacial channel trajectory identified in the GPR data. These fractures were later verified in the field and are likely to be the result of ice weakening in the marginal zone due to surface downwasting combined with channel melting.

In contrast to the eastern channel location, the western channel location at the HGdA was found to agree with the Shreve hydraulic potential results for fully pressurized and partially pressurized flow ( $c=1$, Fig. $7 d ; c=0.5$, Fig. $7 \mathrm{c}$ ). Based on this result, it may be possible that the marginal channel positions are inherited from when the ice was thicker and flow conditions were predominantly pressurized. Once established and eroded into the sediment and bedrock, they could only migrate a small amount during the relatively short summer season. In winter, creep closure due to ice overburden pressure would not be strong enough to close the pre-existing channels entirely as the ice is too thin in this zone. Calculation using Glen's flow law (Glen, 1958; Hooke, 1984) for an ice thickness of $45 \mathrm{~m}$ and a subglacial channel diameter of $4 \mathrm{~m}$ yields a channel closure rate of $1.2 \mathrm{~m}$ per year meaning that, assuming an 8-month-long winter season, channels would close only by up to one-fifth of their total estimated height.

The detected approximate channel planform geometry at the $\mathrm{GdO}$ is different from that at the HGdA in that the channel is more tortuous and resembles a meandering river (Fig. 8d). It eventually reaches a principal outlet at the glacier terminus, which is not directly visible in the orthoimage in Figure $3 \mathrm{~b}$ but was verified in the field in the autumn of 2018 . The channel position was also confirmed by aerial imagery acquired in 2017 and 2018 (Figs 8e and 8f), which document the progressive collapse of the glacier at the precise location where the channel was identified using GPR. The fact that the detected channel roughly coincides with the drainage pathway determined from the Shreve potential calculations, but deviates from the main pathway in a large meandering turn, suggests that local bedrock topography and sediment dynamics may be important factors controlling its course, rather than ice overburden pressure as suggested by Shreve (1972) and the simplest form of the theory of Röthlisberger (1972).

Both the HGdA and GdO were found to have similar ice thicknesses at their glacier tongues (Figs $6 \mathrm{c}$ and $8 \mathrm{c}$ ), and are underlain by similar types of bedrocks. However, their glacier bed compositions differ. At the $\mathrm{GdO}$, field observations indicate that the glacier bed consists of uneven bedrock partly covered by a thin sediment layer (i.e. hummocky terrain) whereas at the HGdA it consists of bedrock covered by a thicker and more even sediment layer (Fischer and Hubbard, 1999). This leads to a more uniform glacier bed topography at the HGdA and to less tortuous subglacial channel planforms.

Both the cracks in the ice above the identified subglacial channels at the HGdA, visible on the aerial photo of September 2015 (Fig. 6f), and the channel breakdown at the GdO, shown on the orthophoto of August 2018 (Fig. 8f) point to a potentially important mechanism that has been rarely documented. It appears that temperate alpine glaciers in a rapidly warming climate are not only losing mass due to melting at the surface and via basal melting, but also due to the removal of large volumes of ice via the collapse and disintegration of subglacial channels. Subglacial channel collapse has indeed been observed in a small number of other studies (Konrad, 1998; Bartholomaus and others, 2011; Stocker-Waldhuber and others, 2017), and the research presented here leads us to the hypothesis that the collapse is related to a situation where surface melt reduces ice thickness at the snout margin and thereby also the extent of winter closure of the subglacial channel. Continued surface melt eventually leads to structural weaknesses in the ice and collapse. If this hypothesis can be confirmed with a detailed analysis of surface displacement and melt, 
it would corroborate the findings of the above studies, as well as suggest that the effects of subglacial channel collapse may be more important for rapid glacier retreat on a global scale than previously assumed.

Our results for the HGdA and GdO show that 3-D analysis of high-resolution, densely acquired GPR data is useful for detecting channel planforms underneath temperate alpine glaciers. Such channel planforms are important for understanding the role that snout marginal channels play in the export of sediment. Depending on the channel geometry and glacier bed topography, the shear stress distribution at the glacier bed varies and this in turn will influence the sediment transport capacity of the conduit (Chen and others, 2018; Perolo and others, 2019). With future glacier retreat and thinning, the subglacial drainage networks underneath the HGdA and the GdO are likely to extend further up-glacier due to an upward shift of the ELA, leading to more meltwater input at higher elevations (Nienow and others, 1998; Beaud and others, 2018). The drainage networks will thereby access new sediment sources underneath the glaciers (Nienow and others, 1998; Swift and others, 2005; Gulley and others, 2012a), leading to changes in sediment fluxes further downstream.

\subsection{Methodological challenges}

Reliable identification of the glacier bed reflection is critical for the successful detection of subglacial channels using the methodology described in this paper. In this regard, a number of factors can affect the quality and interpretability of this reflection. First, englacial scattering due to inclusions of water or voids in temperate ice may strongly attenuate the GPR signal, thereby reducing the radar energy reaching the bed as well as adding significant complexity to the corresponding data (Plewes and Hubbard, 2001; Fig. 4b). Second, the combination of GPR antenna radiation pattern, survey line orientation, and underlying bedrock topography may lead to poor visibility and detection of the glacier bed in some cases (Moran and others, 2003; Rutishauser and others, 2016; Langhammer and others, 2017). Finally, internal layering of the glacier ice, including sediment layers, may complicate the interpretation of the GPR data because layering close to the glacier bed may be difficult to distinguish from the bed reflection (Lapazaran and others, 2016). Despite these challenges, we found that we were able to easily identify the glacier bed in both the HGdA and GdO datasets along most of our survey lines. Indeed, GPR measurements made using the same real-time-sampling instrument much higher up on the HGdA (data not shown) indicated that identification of the bed reflection was even possible where the ice thickness was on the order of 100 $\mathrm{m}$. Note that, in instances where identification of the bed reflection was difficult, analysis of the 3-D GPR datasets in both the survey in-line and cross-line directions proved to be helpful.

Another important consideration for the success of the methodology presented in this paper is the reliability of the amplitude information extracted at the glacier bed. A number of factors can influence the spatial pattern of such amplitudes, which include the quality of the data migration as well as spatial variations in englacial attenuation and scattering that are not taken into account when using a standard, spatially invariant gain function. Furthermore, even in a best-case scenario where the data have been perfectly migrated and attenuation and scattering in the ice have been perfectly compensated, the horizontal resolution of the GPR image at the glacier bed will still be on the order of the dominant wavelength of the GPR pulse (e.g. Stolt and Benson, 1986), which for our $70-\mathrm{MHz}$ system is $\sim 2 \mathrm{~m}$. This means that, at the very least, the images of bed reflection amplitude obtained from the GPR data will represent laterally smeared versions of reality, and that the results presented in Figures $6 \mathrm{~d}$ and 8d must therefore be considered as noisy, low-pass-filtered versions of the true bed reflectivity distribution. Nevertheless, the research presented in this paper demonstrates that such GPR-derived amplitude maps can still offer clear and insightful information regarding the location of subglacial channels. Indeed, the uncertainties that we observed through our repeat-line analysis at the GdO (Figs S1 and S2 in Supplementary material) showed that variations in the recovered amplitudes along the line with time were significantly less than those associated with the presence of subglacial channels.

A further factor influencing the accuracy of our processed GPR images is spatial variability in the subsurface radar wave velocity, the latter of which we assumed to be equal to a constant value of $0.16 \mathrm{~m} \mathrm{~ns}^{-1}$ in our analysis. Because of the common-offset nature of the acquired data, more detailed velocity information was not available and the selected value, which is consistent with other velocities published for temperate ice (Plewes and Hubbard, 2001; Murray and others, 2007), tended to provide the best collapse of diffraction hyperboloids. As a result, errors may exist in the identified location of the glacier bed due to localized velocity variations caused by zones of increased ice water content and the presence of water- and air-filled channels. Nevertheless, these types of errors do not impact the determined planform geometry of the subglacial channels because reflection amplitudes are analyzed along the manually picked glacier-bed reflection.

Finally, despite the fact that we have considered 3-D GPR datasets consisting of densely spaced parallel survey lines in this study, a strong spatial sampling bias exists in these data in the sense that the line spacing ( $1 \mathrm{~m}$ for the HGdA and $2 \mathrm{~m}$ for the GdO) is significantly greater than the spacing of measurements along the lines ( $\sim 0.2 \mathrm{~m}$ for both datasets). Consequently, migration will not perfectly collapse hyperboloids into points and artifacts may exist in the processed data (Grasmueck and others, 2005). Close examination of GPR profiles before and after migration (Fig. 4) was performed in order to check for major artifacts that may have significantly altered our results. In future studies, the line spacing for such 3-D analyses should be kept as small as possible (ideally $0.5-1.0 \mathrm{~m}$ ), although the corresponding surveys would become extremely laborious for regions larger than those considered here. One potential solution is to perform the GPR work via drone, following a precise grid with dGPS navigation and maintaining a minimum distance from the glacier surface.

\section{Conclusions}

The use of densely spaced survey lines in conjunction with dGPS navigation enabled us to record high-resolution 3-D GPR datasets in the snout marginal zones of two alpine glaciers. Amplitude analysis of the GPR reflection along the glacier bed made it possible to reveal areas with a significant change in bed reflectivity, which allows for the identification of subglacial channels that may otherwise be difficult to detect on individual GPR profiles.

The subglacial channels detected at the HGdA and GdO sites measure several meters in width but exhibit different planform geometries. The two channels observed at the HGdA are only slightly meandering, whereas the channel detected at the GdO meanders strongly. We suspect that this difference is a result of differences in glacier bed topography, with the GdO bed being composed of bedrock outcrops and a thin sediment layer, and the HGdA bed being overlain by a thicker sediment layer and presenting a more uniform topography.

Assessment of aerial imagery acquired before and after the GPR surveys, as well as computation and analysis of the Shreve hydraulic potential, allowed us to validate the channel positions identified in the GPR results. The occurrence of cracks at the glacier surface at the HGdA and the collapse of a subglacial channel 
at the GdO coincide perfectly with the GPR-derived channel positions. The principal flowpaths computed from the Shreve potential closely match these channel positions, despite the relatively coarse grid size available for the Shreve analysis.

The results presented in this paper show the potential for 3-D analysis of high-density GPR data acquired on temperate alpine glaciers to provide detailed information about subglacial hydrology. Future drone-supported GPR surveys with a larger spatial extent may yield valuable knowledge about en- and subglacial channel pathways, possibly in 3-D, underneath rapidly retreating alpine glaciers. This information is critical for better understanding of the drainage pathways, hydraulic properties and sediment export potential of such channels as glaciers retreat and new sediment sources at the glacier bed become accessible due to upstream extension of the subglacial drainage network. With further atmospheric warming, the disintegration and collapse of subglacial channels may become an even more important mechanism contributing to the rapid retreat of temperate alpine glaciers in the near future.

Supplementary material. The supplementary material for this article can be found at https://doi.org/10.1017/jog.2021.26

Acknowledgements. We thank Ludovic Baron for help with development of the GPR acquisition system and fieldwork at the HGdA, as well as Boris Ouvry and Martino Sala for help with fieldwork at the GdO. GPR-derived bed topography data for the HGdA were provided by Ian Willis at the University of Cambridge. GPR-derived bed topography data for the GdO were provided by Mauro Werder at ETH Zurich. This research was supported by the University of Lausanne and the Canton de Vaud, Switzerland. Two anonymous reviewers and Editor Dustin Schroeder provided very valuable comments on a previous version of this manuscript.

\section{References}

Alley RB (1992) How can low-pressure channels and deforming tills coexist subglacially? Journal of Glaciology 38(128), 200-207.

Alley RB and 5 others (1997) How glaciers entrain and transport basal sediment: physical constraints. Quaternary Science Reviews 16(9), 1017-1038.

Allroggen N, Tronicke J, Delock M and Böniger U (2015) Topographic migration of $2 \mathrm{D}$ and $3 \mathrm{D}$ ground-penetrating radar data considering variable velocities. Near Surface Geophysics 13(3), 253-259.

Bartholomaus TC, Anderson RS and Anderson SP (2011) Growth and collapse of the distributed subglacial hydrologic system of Kennicott Glacier, Alaska, USA, and its effects on basal motion. Journal of Glaciology 57 (206), 985-1002.

Beaud F, Flowers GE and Venditti JG (2018) Modeling sediment transport in ice-walled subglacial channels and its implications for esker formation and proglacial sediment yields. Journal of Geophysical Research: Earth Surface 123(12), 3206-3227.

Benn D, Gulley J, Luckman A, Adamek A and Glowacki PS (2009a) Englacial drainage systems formed by hydrologically driven crevasse propagation. Journal of Glaciology 55(191), 513-523.

Benn DI, Kristensen L and Gulley JD (2009b) Surge propagation constrained by a persistent subglacial conduit, Bakaninbreen-Paulabreen, Svalbard. Annals of Glaciology 50(52), 81-86.

Bingham RG and Siegert MJ (2007) Radio-echo sounding over polar ice masses. Journal of Environmental and Engineering Geophysics 12(1), 47-62.

Bælum K and Benn DI (2011) Thermal structure and drainage system of a small valley glacier (Tellbreen, Svalbard), investigated by ground penetrating radar. The Cryosphere 5(1), 139-149.

Booth AD, Linford NT, Clark RA and Murray T (2008) Three-dimensional, multi-offset ground-penetrating radar imaging of archaeological targets. Archaeological Prospection 15(2), 93-112.

Chen Y, Liu X, Gulley JD and Mankoff KD (2018) Subglacial conduit roughness: insights from computational fluid dynamics models. Geophysical Research Letters 45(20), 11-206.

Church G, Grab M, Schmelzbach C, Bauder A and Maurer H (2020) Monitoring the seasonal changes of an englacial conduit network using repeated ground-penetrating radar measurements. The Cryosphere 14(10), 3269-3286.

Church G and 5 others (2019) Detecting and characterising an englacial conduit network within a temperate Swiss glacier using active seismic, ground penetrating radar and borehole analysis. Annals of Glaciology 60(79), 193205.

Cook JC (1960) Proposed monocycle-pulse very-high-frequency radar for airborne ice and snow measurement. Transactions of the American Institute of Electrical Engineers, Part I: Communication and Electronics 79(5), 588-594.

Davis JL and Annan AP (1989) Ground-penetrating radar for high-resolution mapping of soil and rock stratigraphy. Geophysical Prospecting 37(5), 531-551.

Farinotti D, Huss M, Bauder A and Funk M (2009a) An estimate of the glacier ice volume in the Swiss Alps. Global and Planetary Change 68(3), 225-231.

Farinotti D, Huss M, Bauder A, Funk M and Truffer M (2009b) A method to estimate the ice volume and ice-thickness distribution of alpine glaciers. Journal of Glaciology 55(191), 422-430.

Fischer U and Hubbard B (1999) Subglacial sediment textures: character and evolution at Haut Glacier d'Arolla, Switzerland. Annals of Glaciology 28, 241-246.

Fountain AG and Walder JS (1998) Water flow through temperate glaciers. Reviews of Geophysics 36(3), 299-328.

Gabbi J, Farinotti D, Bauder A and Maurer H (2012) Ice volume distribution and implications on runoff projections in a glacierized catchment. Hydrology and Earth System Sciences 16(12), 4543-4556.

Gabbud C, Micheletti N and Lane SN (2016) Response of a temperate alpine valley glacier to climate change at the decadal scale. Geografiska Annaler: Series A, Physical Geography 98(1), 81-95.

Geological Atlas of Switzerland (2020) Available at http://www.map.geo. admin.ch.

GLAMOS (1881-2019) The Swiss Glaciers 1880-2016/17, Glaciological Reports No 1-138, Yearbooks of the Cryospheric Commission of the Swiss Academy of Sciences (SCNAT), published since 1964 by VAW / ETH Zurich.

Glen JW (1958) The flow law of ice: a discussion of the assumptions made in glacier theory, their experimental foundations and consequences. IASH Publ, 47(171), el83.

Grasmueck M, Weger R and Horstmeyer H (2005) Full-resolution 3D GPR imaging. Geophysics 70(1), K12-K19.

Gulley JD, Benn DI, Screaton E and Martin J (2009) Mechanisms of englacial conduit formation and their implications for subglacial recharge. Quaternary Science Reviews 28(19-20), 1984-1999.

Gulley JD and 5 others (2012a) The effect of discrete recharge by moulins and heterogeneity in flow-path efficiency at glacier beds on subglacial hydrology. Journal of Glaciology 58(211), 926-940.

Gulley JD and 5 others (2012b) Conduit roughness and dye-trace breakthrough curves: why slow velocity and high dispersivity may not reflect flow in distributed systems. Journal of Glaciology 58(211), 915-925.

Gulley JD and 5 others (2014) Large values of hydraulic roughness in subglacial conduits during conduit enlargement: implications for modeling conduit evolution. Earth Surface Processes and Landforms 39, 296-310.

Hooke R (1984) On the role of mechanical energy in maintaining subglacial water conduits at atmospheric pressure. Journal of Glaciology 30(105), 180-187.

Hubbard B, Sharp M, Willis IC, Nielsen MK and Smart C (1995) Borehole water-level variations and the structure of the subglacial hydrological system of Haut Glacier d'Arolla, Valais, Switzerland. Journal of Glaciology 41(139), 572-583.

Huss M, Jouvet G, Farinotti D and Bauder A (2010) Future high-mountain hydrology: a new parameterization of glacier retreat. Hydrology and Earth System Sciences 14(5), 815-829.

Konrad SK (1998) Possible outburst floods from debris-covered glaciers in the Sierra Nevada, California. Geografiska Annaler: Series A, Physical Geography 80(3-4), 183-192.

Kulessa B, Booth AD, Hobbs A and Hubbard AL (2008) Automated monitoring of subglacial hydrological processes with ground-penetrating radar (GPR) at high temporal resolution: scope and potential pitfalls. Geophysical Research Letters 35(24), L24502.

Langhammer L, Rabenstein L, Bauder A and Maurer H (2017) Ground-penetrating radar antenna orientation effects on temperate mountain glaciers. Geophysics 82(3), H15-H24.

Lapazaran JJ, Otero J, Martín-Español A and Navarro FJ (2016) On the errors involved in ice-thickness estimates I: ground-penetrating radar measurement errors. Journal of Glaciology 62(236), 1008-1020. 
Mair DW, Nienow P, Sharp MJ, Wohlleben T and Willis IC (2002a) Influence of subglacial drainage system evolution on glacier surface motion: Haut Glacier d'Arolla, Switzerland. Journal of Geophysical Research 107(B8), EPM-8.

Mair DW, Sharp MJ and Willis IC (2002b) Evidence for basal cavity opening from analysis of surface uplift during a high-velocity event: Haut Glacier d'Arolla, Switzerland. Journal of Glaciology 48(161), 208-216.

Mair D and 5 others (2003) Hydrological controls on patterns of surface, internal and basal motion during three 'spring events': Haut Glacier d'Arolla, Switzerland. Journal of Glaciology 49(167), 555-567.

Mankoff KD and 7 others (2017) Roughness of a subglacial conduit under Hansbreen, Svalbard. Journal of Glaciology 63(239), 423-435.

Moran ML, Greenfield RJ and Arcone SA (2003) Modeling GPR radiation and reflection characteristics for a complex temperate glacier bed GPR Glacier Reflections. Geophysics 68(2), 559-565.

Murray T, Booth A and Rippin DM (2007) Water-content of glacier-ice: limitations on estimates from velocity analysis of surface ground-penetrating radar surveys. Journal of Environmental and Engineering Geophysics 12(1), 87-99.

Murray T, Stuart GW, Fry M, Gamble NH and Crabtree MD (2000) Englacial water distribution in a temperate glacier from surface and borehole radar velocity analysis. Journal of Glaciology 46(154), 389-398.

Nienow P, Sharp M and Willis I (1996) Temporal switching between englacial and subglacial drainage pathways: dye tracer evidence from the Haut Glacier d'Arolla, Switzerland. Geografiska Annaler. Series A, Physical Geography $\mathbf{7 8}$ (1), 51.

Nienow P, Sharp M and Willis I (1998) Seasonal changes in the morphology of the subglacial drainage system, Haut Glacier d'Arolla, Switzerland. Earth Surface Processes and Landforms 23(9), 825-843.

Nye JF (1959) The motion of ice sheets and glaciers. Journal of Glaciology 3 (26), 493-507.

Paul F (submitter) and 11 others (2019) GLIMS Glacier Database. Boulder, CO: National Snow and Ice Data Center.

Perolo P and 5 others (2019) Subglacial sediment production and snout marginal ice uplift during the late ablation season of a temperate valley glacier. Earth Surface Processes and Landforms 44(5), 1117-1136.

Plewes LA and Hubbard B (2001) A review of the use of radio-echo sounding in glaciology. Progress in Physical Geography 25(2), 203-236.

Röthlisberger H (1972) Water pressure in intra- and subglacial channels. Journal of Glaciology 11(62), 177-203.

Rutishauser A, Maurer H and Bauder A (2016) Helicopter-borne groundpenetrating radar investigations on temperate alpine glaciers: a comparison of different systems and their abilities for bedrock mapping. Geophysics $\mathbf{8 1}$ (1), WA119-WA129.

Salzmann N, Machguth H and Linsbauer A (2012) The Swiss Alpine glaciers' response to the global '2 C air temperature target'. Environmental Research Letters 7(4), 044001.
Schneider WA (1978) Integral formulation for migration in two and three dimensions. Geophysics 43(1), 49-76.

Schroeder DM and 9 others (2020) Five decades of radioglaciology. Annals of Glaciology 61(81), 1-13.

Schwanghart W, Groom G, Kuhn NJ and Heckrath G (2013) Flow network derivation from a high resolution DEM in a low relief, agrarian landscape. Earth Surface Processes and Landforms 38(13), 1576-1586.

Schwanghart W and Scherler D (2014) TopoToolbox 2-MATLAB-based software for topographic analysis and modeling in Earth surface sciences. Earth Surface Dynamics 2(1), 1-7.

Sharp M and 6 others (1993) Geometry, bed topography and drainage system structure of the Haut Glacier d'Arolla, Switzerland. Earth Surface Processes and Landforms 18(6), 557-571.

Shreve RL (1972) Movement of water in glaciers. Journal of Glaciology 11(62), 205-214.

Steenson BO (1951) Radar methods for the exploration of glaciers (Doctoral dissertation, California Institute of Technology).

Stocker-Waldhuber M, Fischer A, Keller L, Morche D and Kuhn M (2017) Funnel-shaped surface depressions - indicator or accelerant of rapid glacier disintegration? A case study in the Tyrolean Alps. Geomorphology 287, 58-72.

Stolt RH and Benson A (1986) Seismic Migration: Theory and Practice. London: Geophys. Press, 382 pp.

Swift DA, Nienow PW and Hoey TB (2005) Basal sediment evacuation by subglacial meltwater: suspended sediment transport from Haut Glacier d'Arolla, Switzerland. Earth Surface Processes and Landforms 30(7), 867883

Swisstopo (2020) SwissAlti3D Digital Elevation Model datasets. Available at https://www.swisstopo.admin.ch/en/home.html.

Taner MT, Koehler F and Sheriff RE (1979) Complex seismic trace analysis. Geophysics 44(6), 1041-1063.

Temminghoff M, Benn DI, Gulley JD and Sevestre H (2019) Characterization of the englacial and subglacial drainage system in a high Arctic cold glacier by speleological mapping and ground-penetrating radar. Geografiska Annaler: Series A, Physical Geography 101(2), 98-117.

Tranter $\mathbf{M}$ and 5 others (2002) Geochemical weathering at the bed of Haut Glacier d'Arolla, Switzerland - a new model. Hydrological Processes 16 959-993.

Walder JS and Fowler A (1994) Channelized subglacial drainage over a deformable bed. Journal of Glaciology 40, 3-15.

Wilson NJ, Flowers GE and Mingo L (2014) Mapping and interpretation of bed-reflection power from a surge-type polythermal glacier, Yukon, Canada. Annals of Glaciology 55(67), 1-8.

Zirizzotti A and 6 others (2010) Dry-wet bedrock interface detection by radio echo sounding measurements. IEEE Transactions on Geoscience and Remote Sensing 48(5), 2343-2348. 